\title{
Neonatal Immunization
}

\section{Richa Sharma*}

Assistant Professor Paediatrics, Department of Paediatrics, SLBS GMC, Nerchowk Mandi, Himachal Pradesh, India

*Corresponding Author: Richa Sharma, Assistant Professor Paediatrics, Department of Paediatrics, SLBS GMC, Nerchowk Mandi, Himachal Pradesh, India. DOI: 10.31080/ASPE.2020.03.0212
Received: January 17, 2020;

Published: January 31, 2020

(C) All rights are reserved by Richa Sharma.

\begin{abstract}
Although vaccines have been quiet successful in reducing the large burden of serious infections. Neonates still remain quiet vulnerable to life-threatening infections. They take their greatest toll during the early stages of life. Hence various approaches are required to protect them. Here we review the rationale, current state, and research for such approach i.e neonatal immunization. There are many challenges to neonatal immunization. Few of them include concern regarding the safety of the vaccine and distinct neonatal immune system (vaccines which are effective in adults are not effective in new borns). Despite distinct neonatal immunity, there are several vaccines which have proven safe and effective at birth. However neonatal immunization at birth is quiet a reliable point of healthcare contact, so is an opportunity for early protection of neonates against diseases, including preterms which are deficient in passively transferred maternal antibodies. While some vaccines such as polysaccharide vaccines have little effectiveness at birth, hepatitis B vaccine can prime at birth and requires multiple doses to achieve protection, contrary to the BCG vaccine which, offers single shot protection.
\end{abstract}

Keywords: Neonatal; Vaccine; Protection; Immunity

\section{Introduction}

Many of the deaths in less than five years are cause to diseases against which vaccines are available. These diseases occur before the protection is provided by routine vaccination. Which usually starts at 6 - 8 weeks of age, as single shot usually is not effective in providing protection, hence repeated doses are required. Hence to reduce the under five mortality a number of strategies are being explored and implemented. We rely on immunization during the early years of life, along with our understanding of neonatal immune responses [1-6]. This has led to keen interest in neonatal immunization. Development in the field of immunization over the past century has led to the discovery of large number of effective vaccines being given at early stages of life. Usually only three vaccines are given at birth which are Bacille Calmette-Guérin (BCG), hepatitis B (HBV), and polio vaccine [oral polio vaccine (OPV); or inactivated polio vaccine (IPV)]. Hence neonatal immunization is a hot topic for future research. Neonatal vaccines are defined as those given "at birth" or within 28 days of life. And infant vaccines given after one month of life. Neonatal vaccines must take into account some limitations, like (a) safety, (b) lack of effectiveness in early life, (c) blunting of neonatal antibody responses because of maternal immunization. However, the rationale for neonatal im- munization is quiet logical as it protects from the burden of early life infections and birth of a child is a potential point of contact with health care facility and pairing immunization with birth is beneficial for both mother and child. Over and above immunization at birth can provide earlier protection. And even protection of preterms for whom maternal antibody transfer was limited. It is evidenced that the benefits of the live-attenuated BCG and other live vaccines is best in early life $[7,8]$. Review of literature has mentioned that both cellular and antibody mediated immune systems are distinct at birth $[9,10]$. Neonatal immunity given by vaccines should not only protect the new born against pathogens, but also help in colonizing of microbes. Cellular immunity in the newborn has reduced Th1 response but high anti-inflammatory IL-10 responses. It has high frequency of regulatory-T cells and CD71+ erythroid precursors that limit, responses to pertussis immunization $[10,12,13]$. Whereas neonatal immunity mounts antigen-specific responses, as seen in BCG vaccination at birth $[14,15]$.

\section{Conclusion}

However, detailed study of age-specific immunity may help in formulation of vaccines. It $i$ is a universal practice to protect new borns against potential life threatening diseases right from birth, yet robust and potential steps and measures are to optimize its benefits and its vast coverage. 


\section{Bibliography}

1. Basha S., et al. "Immune responses in neonates". Expert Review of Clinical Immunology 10 (2014): 1171-1184.

2. Plotkin Stanley A. "Vaccines: Correlates of vaccine-induced immunity". Clinical Infectious Diseases 47 (2008): 401-409.

3. Permar SR., et al. "Role of CD8+ lymphocytes in control and clearance of measles virus infection of rhesus monkeys". Journal of Virology 77 (2003): 4396-4400.

4. Permar SR., et al. "Increased thymic output during acute measles virus infection”. Journal of Virology 77 (2003): 7872-7879.

5. Slifka MK. "Immunological memory to viral infection". Current Opinion in Immunology 16 (2004): 443-450.

6. Fletcher HA. "Correlates of immune protection from tuberculosis". Current Molecular Medicine 7 (2007): 319-325.

7. Strikas RA., et al. "Advisory committee on immunization practices Advisory Committee on Immunization P, Group ACAIW. Advisory committee on immunization practices.

8. Wood N and Siegrist CA. "Neonatal immunization: Where do we stand?" Current Opinion in Infectious Diseases 24 (2011): 190-195.

9. Myers HI., et al. "A retrospective study of administration of vaccination for hepatitis $b$ among newborn infants prior to hospital discharge at a Midwestern tertiary care center". Vaccine 33 (2015): 2316-2321.

10. Cao LH., et al. "Efficacy of combined hepatitis B immunoglobulin and hepatitis B vaccine in blocking father-infant transmission of hepatitis B viral infection". Genetics and Molecular Research 14 (2015): 4651-4657.

11. Fakharzadeh S., et al. "The new nano-complex, Hep-C, improves the immunogenicity of the hepatitis B vaccine". Vaccine 31 (2013): 2591-2597.

12. Lambert L., et al. "Immunity to RSV in early-life". Frontiers in Immunology 5 (2014): 466.

13. Zaghouani H., et al. "Neonatal immunity: Faulty T-helpers and the shortcomings of dendritic cells". Trends in Immunology 30 (2009): 585-591.

14. Locht $\mathrm{C}$ and Mielcarek N. "New pertussis vaccination approaches: En route to protect newborns?" FEMS Immunology and Medical Microbiology 66 (2012):121-133.

15. Prevention CDC. "Guidelines for vaccinating pregnant women". US Food and Drug Administration (2015).

\section{Assets from publication with us}

- Prompt Acknowledgement after receiving the article

- Thorough Double blinded peer review

- Rapid Publication

- Issue of Publication Certificate

- High visibility of your Published work

Website: www.actascientific.com/

Submit Article: www.actascientific.com/submission.php

Email us: editor@actascientific.com

Contact us: +919182824667 